\title{
Acute cholecystitis in patients with diabetes mellitus - systematic review
}

\author{
Monika Kącka $\oplus^{\circledR}$, Piotr Spychalski ${ }^{\circledR}$, Małgorzata Dobrzycka ${ }^{\circledR}$, \\ Olga Rostkowska $₫$, Jarosław Kobiela
}

Department of General, Endocrine and Transplant Surgery of University Clinical Center in Gdańsk, Poland

\begin{abstract}
Introduction: According to the WHO, an estimated 422 million people are suffering from diabetes worldwide. Among them, the incidence of cholelithiasis is higher than in the healthy population. The aim of this literature review was to summarize the available evidence about acute cholecystitis in patients with diabetes. Materials and methods: This study adhered to the PRISMA guidelines. The course of hospitalization of patients with and without diabetes who underwent cholecystectomy due to acute cholecystitis was compared. Following information was abstracted from original studies: general study information, patient characteristics, complications, and recommendations for patients with diabetes. Results: Initial search provided 1632 results. After full text assessment, 40 studies met the inclusions criteria. Operative and postoperative complication rates were significantly higher among the diabetic patients. Diabetes is a risk factor for conversion from laparoscopic to open cholecystectomy method. The authors' opinions on elective surgery before the onset of acute cholecystitis symptoms are divided. Conclusions: Diabetic patients are at greater risk of developing complications. An individualized screening and treatment approach, as well as proper preparation of the diabetic patient for an elective cholecystectomy could have a positive effect on the outcome. However, the low quality of the data from the systematic review does not allow for meta-analysis, which is why we cannot draw strong conclusions.
\end{abstract}

Keywords: diabetes and metabolism · general surgery

\section{Citation}

Łącka M, Spychalski P, Dobrzycka M, Rostkowska O, Kobiela J. Acute cholecystitis in patients with diabetes mellitus - systematic review. Eur J Transl Clin Med. 2019;2(2):71-79.

DOI: $10.31373 /$ ejtcm/115402

Corresponding author:

Monika Łącka, Department of General, Endocrine and Transplant Surgery of University Clinical Center in Gdańsk, Poland

e-mail: lackamonia@gmail.com

No external funds.

Available online: www.ejtcm.gumed.edu.pl

Copyright ${ }^{\circledR}$ Medical University of Gdańsk

This is Open Access article distributed under the terms of the Creative Commons Attribution-ShareAlike 4.0 International. 


\section{Introduction}

According to the latest World Health Organization data, an estimated 422 million people suffer from diabetes worldwide. The incidence of diabetes is increasing rapidly and it is estimated that the number of people with diabetes will double by 2030 . Approximately 104 million new cases of gallbladder and bile duct pathologies are reported annually. Among people suffering from diabetes, the incidence of cholelithiasis is higher than in the healthy population and diabetes increases the risk of developing acute cholecystitis [1-5]. In this group of patients, complications of acute cholecystitis such as gangrenous cholecystitis, bacteriobilia, perforation and emphysematous cholecystitis are more frequent [3-5]. Therefore, acute cholecystitis seems to be a serious problem in diabetic population [6]. However, not many studies were published in the last 30 years on this matter. Moreover, it was reported that cholecystectomy in people with diabetes is related to a significantly higher number of intraoperative complications and almost 3 times higher number of postoperative complications [7]. Once again, the literature about these specific issues is limited.

The aim of this study was to systematically review the available evidence regarding acute cholecystitis in patients suffering from diabetes.

\section{Materials and methods}

This study adhered to the Preferred Reporting Items for Systematic Reviews and Meta-Analysis (PRIMSA) guidelines. We performed a systematic search of the PubMed and Web of Science databases to identify studies on acute cholecystitis in patients with diabetes mellitus published before September $1^{\text {st }}$ 2019. Following search query was used: "(cholecystitis OR cholecystectomy) AND (diabetes OR diabetic) Articles written in languages other than English were excluded. Abstracts, case reports, conference papers, letters, and editorials were excluded during the initial screening of titles and citations. Duplicated results were removed using Mendeley Software. Only full text papers describing the course of hospitalization in patients with diabetes who underwent cholecystectomy due to acute cholecystitis were included in the review (see Figure 1). In the next step we compared the course of hospitalization of patients with and without diabetes who underwent cholecystectomy due to acute cholecystitis.

All steps of the literature search were performed by two independent researchers. Decisions regarding final inclusion were resolved by a consensus.

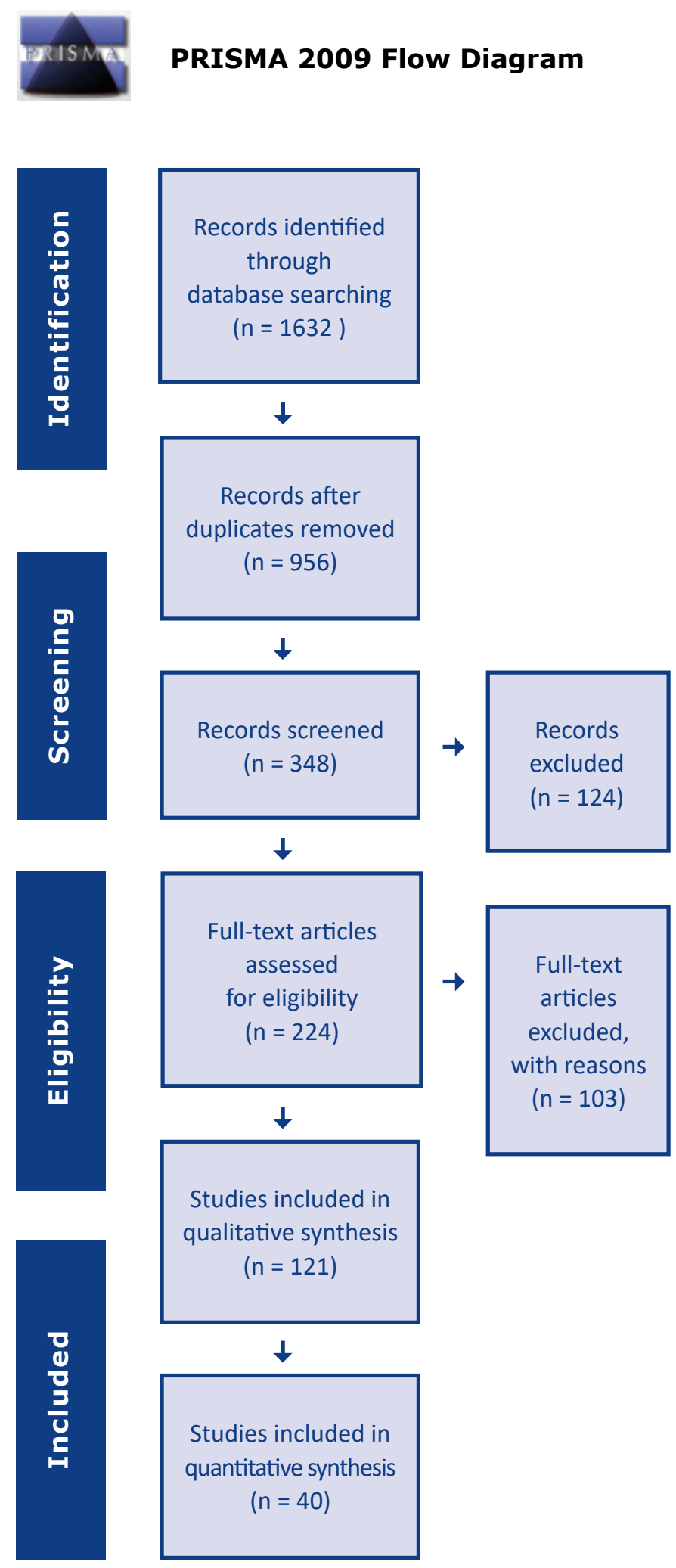

Figure 1. Flowchart illustrating the literature search

From: Moher D, Liberati A, Tetzlaff J, Altman DG, The PRISMA Group (2009). Preferred Reporting Items for Systematic Reviews and Meta-Analyses: The PRISMA Statement. PLoS Med 6(7): e1000097. doi:10.1371/journal.pmed1000097

For more information, visit www.prisma-statement.org. 
The following data was extracted

from the original studies:

1. general study information: authors, publication year, country, institution,

2. demographics: number of patients, sex, age,

3. complications: septic shock, pneumonia, renal insufficiency, cardiovascular complications, (surgical site infection) SSI, wound dehiscence, infectious complications, conversion, preoperative perforation, bleeding, bile leakage, gangrenous cholecystitis, cholelithiasis, perioperative complications, postoperative complications, longer time of operation, anesthesia and total hospitalization time

4. recommendations for patients with diabetes: screening for gallstones, routine cholecystectomy before acute cholecystitis.

\section{Results}

The initial search identified 1632 articles. After excluding articles that do not match the criteria described above, 221 articles were included in the abstract review. Finally, 121 abstracts were selected for full text appraisal of which 40 met all the inclusion criteria and were included in this review. This systematic review included 40 articles including over 1300000 patients. 8 articles did not contain information on the number of patients enrolled in the study. In only 10 articles the patients were grouped by sex. The age of patients enrolled in the study was given in 9 of 40 articles. 22 papers out of 40 were published before 2010, 11 of which contain data from before 2000 . In effect, $25 \%$ of the analyzed literature contains data collected more than 20 years ago (see Table 1).

Table 1. Reviewed articles key data

\begin{tabular}{|c|c|c|c|c|c|c|c|c|}
\hline Authors & $\begin{array}{c}\text { Number } \\
\text { of patients }\end{array}$ & $\begin{array}{l}\text { Men } \\
\%\end{array}$ & $\begin{array}{c}\text { Risk factor } \\
\text { of AC }\end{array}$ & Mortality & $\begin{array}{c}\text { Infectious } \\
\text { complications } \\
\text { during } \\
\text { hospitalization }\end{array}$ & SSI & $\begin{array}{l}\text { Conver- } \\
\text { sion LC } \\
\text { to open } \\
\text { surgery }\end{array}$ & $\begin{array}{l}\text { Postope- } \\
\text { rative } \\
\text { complica- } \\
\text { tions }\end{array}$ \\
\hline $\begin{array}{c}\text { Cho JY et al. } \\
2009 \text { [4] }\end{array}$ & 1059 & 46.36 & $\begin{array}{c}\text { YES, AOR } \\
95 \% \text { CI } 1.802 \\
(1.153-2.816)\end{array}$ & & & & & \\
\hline $\begin{array}{c}\text { Bodmer M } \\
\text { et al. } \\
2011 \text { [24] }\end{array}$ & 22574 & 24.3 & $\begin{array}{c}\text { AOR for } \\
\text { developing } \\
\text { gallstone } \\
\text { disease } \\
\text { followed by } \\
\text { cholecystec- } \\
\text { tomy of } 0.88 \text {, } \\
95 \% \mathrm{CI} \\
78-1.00 \text {, } \\
\mathrm{p}=0.05 \text { ) } \\
\text { that diabetes } \\
\text { mellitus is not } \\
\text { an independent } \\
\text { risk factor for } \\
\text { cholecystectomy. }\end{array}$ & & & & & \\
\hline $\begin{array}{c}\text { De Santis A } \\
\text { et al. } 1999 \\
{[11]}\end{array}$ & 336 & 39.29 & $\begin{array}{c}\text { YES } 11,6 \% \\
\text { VS. } 4,8 \% \\
\text { respectively } \\
\text { OR, } 2.55 ; 95 \% \\
\text { CI, } 1,39-4,67\end{array}$ & & & & & \\
\hline
\end{tabular}




\begin{tabular}{|c|c|c|c|c|c|c|c|c|}
\hline $\begin{array}{c}\text { Karamanos E } \\
\text { et al. } \\
2013 \text { [5] }\end{array}$ & 5460 & 55.4 & YES, NR & $\begin{array}{c}\text { YES (AOR) } \\
(95 \% \mathrm{CI}): 1.79 \\
(1.09,2.94), \\
\text { adjusted } \\
p=0.022]\end{array}$ & $\begin{array}{c}5.6 \text { vs. } 1.6 \% \\
\text { AOR }[95 \% \mathrm{CI}] \\
1.85[1.53,2.23]\end{array}$ & $\begin{array}{c}\text { On insulin vs. } \\
\text { non-diabetics: } \\
4.2 \\
\text { vs } 1.6 \% ; \\
\text { AOR [95\% } \\
\text { CI]: } 1.80 \\
{[1.39,2.34]}\end{array}$ & & \\
\hline $\begin{array}{c}\text { Miguel-Yanes } \\
\text { JM et al. } \\
2016 \text { [12] }\end{array}$ & 611533 & & $\begin{array}{c}\text { YES, } \\
p<0.001\end{array}$ & $\begin{array}{c}\text { After open } \\
\text { cholecystectomy } \\
{[\mathrm{OR}=0.82} \\
(0.78-0.87)] \\
\text { but a higher } \\
\text { IHM after } \\
\text { laparoscopic } \\
\text { cholecystectomy } \\
{[\mathrm{OR}=1.18} \\
(1.03-1.35)] .\end{array}$ & & & & \\
\hline $\begin{array}{l}\text { Turrill FL et } \\
\text { al. } 1961 \text { [36] }\end{array}$ & 481 & & & YES, NR & YES, NR & YES, NR & & \\
\hline $\begin{array}{l}\text { Liu C-M et al. } \\
2015 \text { [22] }\end{array}$ & 108850 & & $\begin{array}{c}\text { YES, MALE } \\
p<0.001\end{array}$ & $\begin{array}{c}53,1 \\
+D 1: D 31\end{array}$ & & & & \\
\hline $\begin{array}{l}\text { Bedirli A et } \\
\text { al. } 2001 \text { [27] }\end{array}$ & 862 & & & YES, NR & & & $\begin{array}{c}\text { YES, } p= \\
0,012\end{array}$ & $\begin{array}{c}\text { YES, } \\
0,0061\end{array}$ \\
\hline $\begin{array}{l}\text { Terho PM et } \\
\text { al. } 2016 \text { [9] }\end{array}$ & 373 & & & & & & $\begin{array}{c}\text { YES, } \\
\text { OR } 2.0 \\
(1.2-3.6) \\
p=0.014\end{array}$ & \\
\hline $\begin{array}{c}\text { Cucchiaro G } \\
\text { et al. } 1989 \\
{[14]}\end{array}$ & & & YES, NR & YES, $p=0.002$ & & & & \\
\hline $\begin{array}{l}\text { Lyass S et al. } \\
2000[15]\end{array}$ & 601 & 26.29 & YES, NR & YES, NR & & & NO, NR & $\begin{array}{c}\text { YES, } \\
p=0.055\end{array}$ \\
\hline $\begin{array}{c}\text { Jaafar G } \\
\text { et al. } \\
2017 \text { [37] }\end{array}$ & 94557 & & & & $\begin{array}{c}\text { YES, complicated } \\
\text { diabetes } \mathrm{p}<0.001 \\
\text { OR } 3.177 \mathrm{CI} \\
2.153-4.689 \\
\text { uncomplicated } \\
\text { diabetes } \\
\mathrm{p}<0.001 \\
\text { OR } 2.943 \mathrm{CI} \\
2.368-3.657\end{array}$ & $\begin{array}{c}\text { YES, } \\
\text { complicated } \\
\text { diabetes (OR } \\
1.435, \mathrm{CI} \\
1.205-1.708), \\
\text { uncomplicated } \\
\text { diabetes (OR } \\
1.391, \mathrm{CI} \\
1.264-1.530)\end{array}$ & & \\
\hline
\end{tabular}




\begin{tabular}{|c|c|c|c|c|c|c|c|c|}
\hline $\begin{array}{l}\text { Lee S et al. } \\
2011 \text { [16] }\end{array}$ & 611 & & $\begin{array}{c}\text { YES, } p=0,002 \\
\text { OR }(95 \% \mathrm{CI}) \\
1,960 \\
(1,262-3,044)\end{array}$ & & & & & \\
\hline $\begin{array}{c}\text { Pagliarulo M } \\
\text { et al. } 2004 \\
{[3]}\end{array}$ & 1337 & 53.1 & $\begin{array}{l}\text { NO, BMI, AGE, } \\
\text { FAMILY, NR }\end{array}$ & & & & & \\
\hline $\begin{array}{c}\text { de Siqueira } \\
\text { Corradi MB } \\
\text { et al. } 2019 \\
{[18]}\end{array}$ & 2520 & & $\begin{array}{c}\text { YES, } \\
\text { adjusted model } \\
2.68<0.001\end{array}$ & $\begin{array}{c}53,1 \\
+D 1: D 31\end{array}$ & & & & \\
\hline $\begin{array}{c}\text { Warren DK } \\
\text { et al. } 2017 \\
{[40]}\end{array}$ & & & & & & $\begin{array}{l}\text { Independent risk } \\
\text { factors for SSI after } \\
\text { cholecystectomy. } \\
\text { Adjusted HR (95\% } \\
\text { CI) } 1.53(1.19-1.98)\end{array}$ & & \\
\hline $\begin{array}{c}\text { Ismat U et al. } \\
2016 \text { [42] }\end{array}$ & 120 & & & & & $\begin{array}{l}\text { Presence of diabetes } \\
\text { mellitus did not si- } \\
\text { gnificantly affect the } \\
\text { onset of surgical site } \\
\text { infection in patients } \\
\text { undergoing laparo- } \\
\text { scopic cholecystecto- } \\
\text { my; } p=0.07\end{array}$ & & \\
\hline $\begin{array}{c}\text { Ibrahim S } \\
\text { et al. } 2006 \\
\text { [34] }\end{array}$ & 1000 & & & & & & $\begin{array}{l}\text { NO, but diabetic } \\
\text { patients who } \\
\text { had conversion } \\
\text { had a signifi- } \\
\text { cantly higher } \\
\text { Hba1c }(8.9 \% \\
+/-0.6 \% ; p< \\
0.038)\end{array}$ & \\
\hline $\begin{array}{c}\text { Philip Rothman } \\
\text { J et al. } 2016 \\
\text { [35] }\end{array}$ & 460995 & & & & & & $\begin{array}{l}\text { None of the } \\
\text { studies were } \\
\text { eligible for } \\
\text { meta-analysis. }\end{array}$ & \\
\hline
\end{tabular}




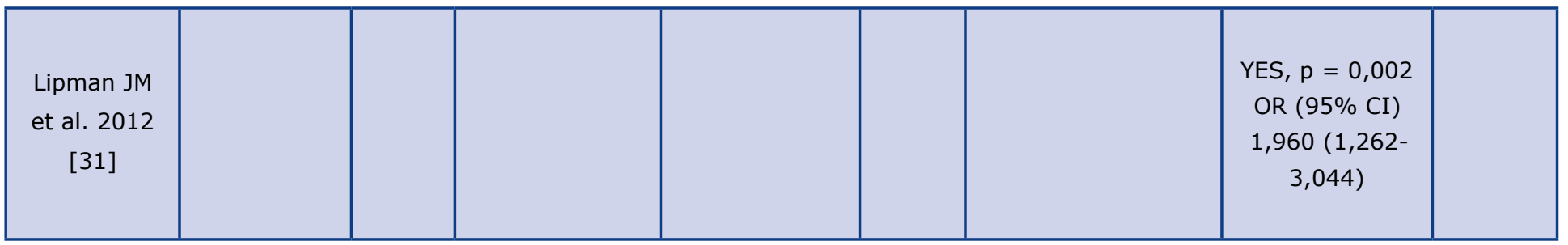

Abbreviations: AC - acute cholecystitis, AOR - adjusted odds ratio, $\mathrm{Cl}$ - confidence interval, Hba1c - glycosylated hemoglobin, HR - hazards ratio, IHM - in- hospital mortality, NR - not recorded, SSI - surgical site infection, LC - laparoscopic cholecystectomy, OR - odds ratio.

\section{Complications}

In 19 of the analyzed articles, diabetes was discussed as an independent risk factor for acute cholecystitis and in 14 of them diabetes was confirmed as an independent risk factor for developing this disease [1, 8-19]. Two studies analyzed this correlation in detail and in one it was significant only for women $(p<$ 0,001 ), while in another it was significant only for men $(p<0,001)$ [20-21]. On the contrary, in 3 studies diabetes was not confirmed as an independent risk factor for acute cholecystitis [22-24].

A total of 15 articles analyzed diabetes as a risk factor for conversion from laparoscopic to open surgery. in 10 studies diabetes was found to increase this conversion rate $[6,10,25-32]$. On the contrary, in 5 studies did not show that diabetes significantly affected the risk of conversion [16, 33-36]. However, in one of these studies it was noted that diabetic patients with higher levels of glycated hemoglobin had a significantly higher risk of conversion [35].

The problem of the number of postoperative complications in patients with diabetes was analyzed in 6 papers [6, 15-16, 18, 22, 32]. Authors of 4 articles noted that complications significantly more frequently affect this group of patients [6, 15-16,32]. In all 6 papers pointed out systemic infectious complications after surgery $[10,13,27,32,37-38]$ and 5 of them concluded that patients with diabetes are more at risk of systemic infectious complications [10, 27, 32, 37-38]. Septic shock as a separately listed postoperative complication appears in one study and its incidence is reported to be significantly higher for patients with diabetes [39].

Surgical site infection (SSI) in patients with diabetes has been discussed by the authors of 8 papers. In 6 articles it was reported that diabetes is a risk factor for SSI [13, 37-38, 40-42]. In one paper diabetes did not affect significantly the incidence of SSI [33]. In another paper, the authors summarized that diabetes did not increase significantly the incidence of SSI during laparoscopic cholecystectomy [43]. Authors of 4 articles analyzed the problem of postoperative wound dehiscence $[10,27,37,39]$. Three of them reported that it significantly more frequently affected patients with diabetes [10, 27, 37]. According to one study, respiratory complications were significantly more frequent in the group of patients with diabetes [33]. Cardiovascular events significantly more often affected patients suffering from diabetes according to 4 articles [10, 13, 37, 43]. The authors of all 3 papers which distinguished renal failure as a postoperative complication reported that the above problem significantly more often affects patients with diabetes [10, 39, 43].

In 9 studies, increased postoperative mortality in diabetics was analyzed. The authors of 7 of them reported that it is significantly higher in patients with diabetes [10, 15-16, 32, 37, 39, 43]. In one paper it was noticed that the mortality was increased only in patients who underwent laparoscopic surgery [13]. The authors of one paper did not observe the correlation between diabetes and increased mortality [18].

\section{Surgical complications}

Just 2 papers examined the problem of intraoperative complications and only one of them confirmed the association between diabetes and the increased incidence of intraoperative complications [27, 32]. Two studies did not find the link between diabetes and increased intraoperative bleeding $[26,33]$. On the other hand, one paper reported that diabetes increases the frequency of bleeding during surgery [27]. The authors of 3 papers reported that pre-operative gallbladder perforation occurs substantially more frequently to patients with diabetes $[9,27,32]$. In 3 studies no difference in the duration of surgery in patients with diabetes was noted, however in one of these studies it was demonstrated that the duration of anesthesia in patients with diabetes is significantly longer [26-27, 32].

\section{The course of hospitalization}

Five studies analyzed the effect of diabetes on prolonged hospitalization after cholecystectomy. Two of those confirm that patients with diabetes require longer hospitalization $[10,26]$. Whereas in the remaining 3 studies, no such correlation was observed [6, 27, 33]. 


\section{Recommendations}

Elective surgery before the onset of symptoms of acute cholecystitis is recommended in 3 papers [15, $44,45]$. Whereas in 3 other articles such recommendation is not made $[18,22,48]$. Three authors discuss routine screening for cholelithiasis [15, 22, 45], and two of those recommend it $[15,45]$. In one paper, the authors point out that patients with diabetes should be operated by laparoscopy because it improves postoperative outcomes [32].

\section{Discussion}

The analyzed studies were very heterogeneous in terms of data quality and data reporting. Surprisingly many articles did not contain basic patient demographics, detailed methodology (e.g. patient inclusion/ exclusion criteria) or full results presented in quantitative data. For these reasons it was impossible to perform a meta-analysis in addition to the systematic review and therefore to draw strong conclusions.

Most authors of the analyzed articles confirm that diabetes is a risk factor for acute cholecystitis, although some authors disagree [22-24]. Based on the literature reviewed, it seems that diabetes is an independent risk factor for acute cholecystitis. Most of the available literature suggests that diabetes is a risk factor for conversion from laparoscopic cholecystectomy to the open approach. Conversion was significantly more common in diabetics with higher $\mathrm{HbA1c}$ levels. The effectiveness of the patient's diabetes treatment affects the severity of biliary disease and can increase the risk of conversion. Postoperative complications seem to affect patients with diabetes more often. According to most authors diabetes is a risk factor for systemic infection, such as pneumonia or UTI. Diabetic patients significantly more often suffer from SSI, wound dehiscence and septic shock. Diabetes is an inde- pendent risk factor for impaired wound healing, which is therefore in agreement with the general view.

The results of the analyzed articles also support the well-known fact that cardiovascular events and renal failure significantly more often affect patients with diabetes. It is noteworthy that the authors also noted a significantly increased postoperative mortality among diabetic patients. This may be directly related to the more frequent development of the above-mentioned complications. Another explanation for the above phenomenon is the more advanced age and more associated diseases discussed by the authors.

Regarding the recommendations for the management of patients with diabetes, the authors disagree whether elective cholecystectomy should be routinely performed in patients with diabetes. Although the EASL 2016 guidelines do not recommend routine cholecystectomy, the higher number of complications and mortality suggests that diabetic patients could benefit from such management [46]. Despite the large population of diabetic patients worldwide, at this time there is not enough high-quality evidence on this topic to formulate the necessary guidelines. An individualized approach, cholelithiasis screening and elective surgery could benefit not only patients but also the healthcare system.

\section{Conclusion}

Patients with diabetes have an increased risk of developing acute cholecystitis. Furthermore, diabetic patients with acute cholecystitis tend to have more complicated course of the disease. An individualized approach and screening in selected cases, as well as elective cholecystectomy after proper preparation of the patient could have a positive effect on the outcome. However, the low quality of the data from the systematic review does not allow for meta-analysis, which is why we cannot draw strong conclusions.

\section{References}

1. Aune D, Vatten LJ. Diabetes mellitus and the risk of gallbladder disease: A systematic review and meta-analysis of prospective studies. J Diabetes Complications [Internet]. 2016 Mar;30(2):368-73. Available from: https://linkinghub.elsevier.com/retrieve/pii/S105687271500450X

2. Chapman BA, Wilson IR, Frampton CM, Chisholm RJ, Stewart NR, Eagar GM, et al. Prevalence of gallbladder disease in diabetes mellitus. Dig Dis Sci [Internet]. 1996 Nov;41(11):2222-8. Available from: http://link.springer.com/10.1007/BF02071404

3. Pagliarulo M. Gallstone disease and related risk factors in a large cohort of diabetic patients. Dig Liver Dis [Internet]. 2004 Feb;36(2):130-4. Available from: https://linkinghub.elsevier.com/retrieve/pii/S1590865803006340

4. Cho JY, Han HS, Yoon YS, Ahn KS. Risk factors for acute cholecystitis and a complicated clinical course in patients with symptomatic cholelithiasis. Arch Surg [Internet]. 2010 Apr 1;145(4):329-33. Available from: http://archsurg.jamanetwork.com/article.aspx?doi=10.1001/archsurg.2010.35 
5. Karamanos E, Sivrikoz E, Beale E, Chan L, Inaba K, Demetriades D. Effect of diabetes on outcomes in patients undergoing emergent cholecystectomy for acute cholecystitis. World J Surg [Internet]. 2013 Oct 16;37(10):2257-64. Available from: https://doi.org/10.1007/s00268-013-2086-6

6. Bourikian S, Anand RJ, Aboutanos M, Wolfe LG, Ferrada P. Risk factors for acute gangrenous cholecystitis in emergency general surgery patients. Am J Surg [Internet]. 2015 Oct;210(4):730-3. Available from: https://doi.org/10.1016/i.amjsurg.2015.05.003

7. Shpitz B, Sigal A, Kaufman Z, Dinbar A. Acute cholecystitis in diabetic patients. Am Surg [Internet]. 1995 Nov;61(11):9647. Available from: http://www.ncbi.nlm.nih.gov/pubmed/7486428

8. Landau O, Deutsch AA, Kott I, Rivlin E, Reiss R. The risk of cholecystectomy for acute cholecystitis in diabetic patients. Hepatogastroenterology [Internet]. 1992 Oct;39(5):437-8. Available from: http://www.ncbi.nlm.nih.gov/pubmed/1459527

9. Terho PM, Leppäniemi AK, Mentula PJ. Laparoscopic cholecystectomy for acute calculous cholecystitis: a retrospective study assessing risk factors for conversion and complications. World J Emerg Surg [Internet]. 2016 Dec 16;11(1):54. Available from: http://wjes.biomedcentral.com/articles/10.1186/s13017-016-0111-4

10. Hickman MS, Schwesinger WH, Page CP. Acute cholecystitis in the diabetic. A case-control study of outcome. Arch Surg [Internet]. 1988 Apr;123(4):409-11. Available from: http://www.ncbi.nlm.nih.gov/pubmed/3348729

11. De Santis A, Attili AF, Ginanni Corradini S, Scafato E, Cantagalli A, De Luca C, et al. Gallstones and diabetes: a case-control study in a free-living population sample. Hepatology [Internet]. 1997 Apr;25(4):787-90. Available from: http://www. ncbi.nlm.nih.gov/pubmed/9096577

12. de Miguel-Yanes JM, Méndez-Bailón M, Jiménez-García R, Hernández-Barrera V, Pérez-Farinós N, Turégano F, et al. Open versus laparoscopic cholecystectomies in patients with or without type 2 diabetes mellitus in Spain from 2003 to 2013. Hepatobiliary Pancreat Dis Int. 2016 Oct;15(5):525-32.

13. ABRAMSON DJ. Diabetes Mellitus and Cholecystectomy. Ann Surg [Internet]. 1957 Mar;145(3):371-8. Available from: https://insights.ovid.com/crossref?an=00000658-195703000-00011

14. Cucchiaro G, Waiters CR, ROSSITCH JC, MEYERS WC. Deaths from Gallstones. Ann Surg [Internet]. 1989 Feb;209(2):14951. Available from: https://insights.ovid.com/crossref?an=00000658-198902000-00002

15. Lyass S, Perry Y, Venturero M, Muggia-Sullam M, Eid A, Durst A, et al. Laparoscopic cholecystectomy: what does affect the outcome? A retrospective multifactorial regression analysis. Surg Endosc [Internet]. 2000 Jul;14(7):661-5. Available from: http://www.ncbi.nlm.nih.gov/pubmed/10948305

16. Lee S, Chung C-W, Ko KH, Kwon SW. Risk factors for the clinical course of cholecystitis in patients who undergo cholecystectomy. Korean J Hepato-Biliary-Pancreatic Surg [Internet]. 2011 Aug;15(3):164. Available from: https://synapse. koreamed.org/DOlx.php?id=10.14701/kjhbps.2011.15.3.164

17. RansohoffDF, Miller GL, ForsytheSB, Hermann RE. Outcome of acutecholecystitisin patients with diabetesmellitus. Ann Intern Med [Internet]. 1987 Jun 1;106(6):829. Available from: http://annals.org/article.aspx?doi=10.7326/0003-4819-106-6-829

18. de Siqueira Corradi MB, D Ávila R, Duim E, Rodrigues CIS. Risk stratification for complications of laparoscopic cholecystectomy based on associations with sociodemographic and clinical variables in a public hospital. Am J Surg [Internet]. 2019 May 15; Available from: https://doi.org/10.1016/i.amjsurg.2019.05.005

19. Paajanen H, Suuronen S, Nordstrom P, Miettinen P, Niskanen L. Laparoscopic versus open cholecystectomy in diabetic patients and postoperative outcome. Surg Endosc [Internet]. 2011 Mar 27;25(3):764-70. Available from: http://link. springer.com/10.1007/s00464-010-1248-y

20. Doran H, Pătraşcu T. Acute abdomen in diabetic patients - what should we do? Chirurgia (Bucur). 2018;113(5):593.

21. Sun H, Tang H, Jiang S, Zeng L, Chen E-Q, Zhou T-Y, et al. Gender and metabolic differences of gallstone diseases. World J Gastroenterol [Internet]. 2009 Apr;15(15):1886. Available from: http://www.wignet.com/1007-9327/full/v15/i15/1886.htm

22. Liu C-M, Chung C-L, Hsu C-T, Song M-Z, Chen C-C, Li C-Y. Impact of diabetes mellitus on cholecystectomy rate: A population-based follow-up study. Formos J Surg [Internet]. 2015 Oct;48(5):157-62. Available from: http://linkinghub.elsevier. com/retrieve/pii/S1682606X15001097

23. Aucott JN, Cooper G, Bloom A, Aron D. Management of Gallstones in Diabetic Patients. Arch Intern Med [Internet]. 1993 May 10;153(9):1053. Available from: http://archinte.jamanetwork.com/article.aspx?doi=10.1001/ archinte.1993.00410090019003

24. Bodmer M, Brauchli YB, Jick SS, Meier CR. Diabetes mellitus and the risk of cholecystectomy. Dig Liver Dis [Internet]. 2011 Sep;43(9):742-7. Available from: https://linkinghub.elsevier.com/retrieve/pii/S159086581100154X

25. Bouassida M, Chtourou MF, Charrada H, Zribi S, Hamzaoui L, Mighri MM, et al. The severity grading of acute cholecystitis following the Tokyo Guidelines is the most powerful predictive factor for conversion from laparoscopic cholecystectomy to open cholecystectomy. J Visc Surg [Internet]. 2017 Sep;154(4):239-43. Available from: https://linkinghub.elsevier. com/retrieve/pii/S1878788616301953 
26. Aldaqal SM, Albaghdadi AT, Tashkandi HM, El-deek BS, Al-Malki GA, Turki AM, et al. Effect of Diabetes Mellitus on Patients Undergoing Laparoscopic Cholecystectomy: A Comparative Cross-Sectional Study. Llife Sci Journal-ActaZ Hengzhou Univ Ovrseas Ed [Internet]. 2012;9(1):431-9. Available from: http://www.lifesciencesite.com/lsj/life0901/

27. Bedirli A, Sözüer EM, Yüksel O, Yilmaz Z. Laparoscopic Cholecystectomy for Symptomatic Gallstones in Diabetic Patients. J Laparoendosc Adv Surg Tech [Internet]. 2001 Oct;11(5):281-4. Available from: http://www.liebertpub.com/ doi/10.1089/109264201317054564

28. Sippey M, Grzybowski M, Manwaring ML, Kasten KR, Chapman WH, Pofahl WE, et al. Acute cholecystitis: risk factors for conversion to an open procedure. J Surg Res [Internet]. 2015 Dec;199(2):357-61. Available from: https://linkinghub.elsevier.com/ retrieve/pii/S0022480415006514

29. Simopoulos C, Botaitis S, Polychronidis A, Tripsianis G, Karayiannakis AJ. Risk factors for conversion of laparoscopic cholecystectomy to open cholecystectomy. Surg Endosc [Internet]. 2005 Jul 4;19(7):905-9. Available from: http://link.springer.com/10.1007/s00464-004-2197-0

30. Costantini R, Caldaralo F, Palmieri C, Napolitano L, Aceto L, Cellini C, et al. Risk factors for conversion of laparoscopic cholecystectomy. Ann Ital Chir [Internet]. 2012;83(3):245-52. Available from: http://www.ncbi.nlm.nih.gov/pubmed/22610122

31. Lipman JM, Claridge JA, Haridas M, Martin MD, Yao DC, Grimes KL, et al. Preoperative findings predict conversion from laparoscopic to open cholecystectomy. Surgery [Internet]. 2007 Oct;142(4):556-65. Available from: https://linkinghub.elsevier.com/ retrieve/pii/s0039606007004357

32. Al-Mulhim ARS. The Outcome of Laparoscopic Cholecystectomy in Diabetic Patients: A Prospective Study. J Laparoendosc Adv Surg Tech [Internet]. 2010 Jun;20(5):417-20. Available from: http://www.liebertpub.com/doi/10.1089/lap.2009.0436

33. Pavlidis TE, Marakis GN, Ballas K, Symeonidis N, Psarras K, Rafailidis S, et al. Risk Factors Influencing Conversion of Laparoscopic to Open Cholecystectomy. J Laparoendosc Adv Surg Tech [Internet]. 2007 Aug;17(4):414-8. Available from: http://www.liebertpub. com/doi/10.1089/lap.2006.0178

34. Ibrahim S, Hean TK, Ho LS, Ravintharan T, Chye TN, Chee CH. Risk Factors for Conversion to Open Surgery in Patients Undergoing Laparoscopic Cholecystectomy. World J Surg [Internet]. 2006 Sep 16;30(9):1698-704. Available from: http://link.springer. com/10.1007/s00268-005-0612-x

35. Philip Rothman J, Burcharth J, Pommergaard H-C, Viereck S, Rosenberg J. Preoperative Risk Factors for Conversion of Laparoscopic Cholecystectomy to Open Surgery - A Systematic Review and Meta-Analysis of Observational Studies. Dig Surg [Internet]. 2016;33(5):414-23. Available from: https://www.karger.com/Article/FullText/445505

36. Turrill FL, McCarron MM, Mikkelsen WP. Gallstones and diabetes: an ominous association. Am J Surg [Internet]. 1961 Aug;102(2):184-90. Available from: https://linkinghub.elsevier.com/retrieve/pii/000296106190383X

37. Jaafar G, Hammarqvist F, Enochsson L, Sandblom G. Patient-Related Risk Factors for Postoperative Infection After Cholecystectomy. World J Surg [Internet]. 2017 Sep 20;41(9):2240-4. Available from: http://link.springer.com/10.1007/s00268-017-4029-0

38. Karamanos E, Dulchavsky S, Beale E, Inaba K, Demetriades D. Diabetes Mellitus in Patients Presenting with Adhesive Small Bowel Obstruction: Delaying Surgical Intervention Results in Worse Outcomes. World J Surg [Internet]. 2016 Apr 13;40(4):863-9. Available from: http://link.springer.com/10.1007/s00268-015-3338-4

39. Aga E, Keinan-Boker L, Eithan A, Mais T, Rabinovich A, Nassar F. Surgical site infections after abdominal surgery: incidence and risk factors. A prospective cohort study. Infect Dis (Auckl) [Internet]. 2015 Nov 2;47(11):761-7. Available from: http://www.tandfonline.com/doi/full/10.3109/23744235.2015.1055587

40. Warren DK, Nickel KB, Wallace AE, Mines D, Tian F, Symons WJ, et al. Risk factors for surgical site infection after cholecystectomy. Open Forum Infect Dis [Internet]. 2017 Apr 1;4(2):ofx036. Available from: https://academic.oup.com/ofid/article/doi/10.1093/ ofid/ofx036/3044173

41. Doran H, Pătraşcu T, Radu C. [Acute abdomen in diabetic patients --diagnostical questions]. Chirurgia (Bucur) [Internet]. 2003;98(2):119-25. Available from: http://www.ncbi.nlm.nih.gov/pubmed/14992132

42. Ismat U, Khan A, Nawaz A, Mansoor R, Malik AA, Sher F, et al. Surgical Site Infection in Diabetic and Non-Diabetic Patients Undergoing Laparoscopic Cholecystectomy. J Coll Physicians Surg Pak [Internet]. 2016 Feb;26(2):100-2. Available from: http://www. ncbi.nlm.nih.gov/pubmed/26876394

43. Sandler RS, Maule WF, Baltus ME. Factors associated with postoperative complications in diabetics after biliary tract surgery. Gastroenterology [Internet]. 1986 Jul;91(1):157-62. Available from: https://linkinghub.elsevier.com/retrieve/pii/001650858690452X

44. Chen L, Peng Y-T, Chen F-L, Tung T-H. Epidemiology, management, and economic evaluation of screening of gallstone disease among type 2 diabetics: A systematic review. World J Clin Cases [Internet]. 2015 Jul;3(7):599. Available from: http://www.wjgnet. com/2307-8960/full/v3/i7/599.htm

45. Del Favero G, Caroli A, Meggiato T, Volpi A, Scalon P, Puglisi A, et al. Natural history of gallstones in non-insulin-dependent diabetes mellitus. Dig Dis Sci [Internet]. 1994 Aug;39(8):1704-7. Available from: http://link.springer.com/10.1007/BF02087780

46. European Association for the Study of the Liver (EASL). Electronic address: easloffice@easloffice.eu. EASL Clinical Practice Guidelines on the prevention, diagnosis and treatment of gallstones. J Hepatol [Internet]. 2016 Jul;65(1):146-81. Available from: https://linkinghub.elsevier.com/retrieve/pii/S0168827816300320 